Keywords:

Plutonium Oxide, Powder, Direct Fabrication

\title{
Development of the Direct Fabrication Process for Plutonium Immobilization (U)
}

\author{
J. W. Congdon, K M. Marshall
}

Publication Date: June 4, 2001

Westinghouse Savannah River Company

Savannah River Site

Aiken, SC 29808 
This document was prepared in conjunction with work accomplished under Contract No.

DE-AC09-96SR18500 with the U.S. Department of Energy.

\section{DISCLAIMER}

This report was prepared as an account of work sponsored by an agency of the United States Government. Neither the United States Government nor any agency thereof, nor any of their employees, makes any warranty, express or implied, or assumes any legal liability or responsibility for the accuracy, completeness, or usefulness of any information, apparatus, product or process disclosed, or represents that its use would not infringe privately owned rights. Reference herein to any specific commercial product, process or service by trade name, trademark, manufacturer, or otherwise does not necessarily constitute or imply its endorsement, recommendation, or favoring by the United States Government or any agency

thereof. The views and opinions of authors expressed herein do not necessarily state or reflect those of the United States Government or any agency thereof.

This report has been reproduced directly from the best available copy.

Available for sale to the public, in paper, from: U.S. Department of Commerce, National Technical Information Service, 5285 Port Royal Road, Springfield, VA 22161, phone: (800)

553-6847, fax: (703) 605-6900, email: orders@ntis.fedworld.gov online ordering: http://www.ntis.gov/ordering.htm

Available electronically at http://www.doe.gov/bridge

Available for a processing fee to U.S. Department of Energy and its contractors, in paper, from: U.S. Department of Energy, Office of Scientific and Technical Information, P.O. Box 62, Oak Ridge, TN 37831-0062, phone: (865 ) 576-8401, fax: (865) 576-5728, email: reports@ adonis.osti.gov 
WSRC-TR-2000-00283

Revision 0

\section{Approvals}

\section{Westinghouse Savannah River Company}

J.W. Congdon, Author

Date

Materials Technology Section

Savannah River Technology Center

K. M Marshall, Author

Date

Materials Technology Section

Savannah River Technology Center

A. D. Cozzi, Technical Reviewer

Date Immobilization Technology Section

Savannah River Technology Center

J. C. Marra, Program Manager

Actinide Technology Section

Savannah River Technology Center

A. L. Blancett, Manager

Date Actinide Technology Section

Savannah River Technology Center 


\section{Table of Contents}

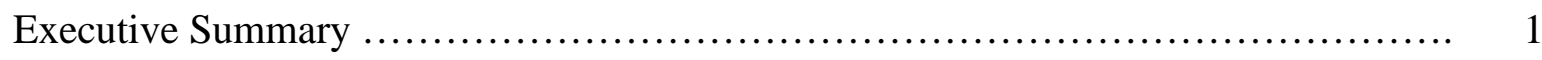

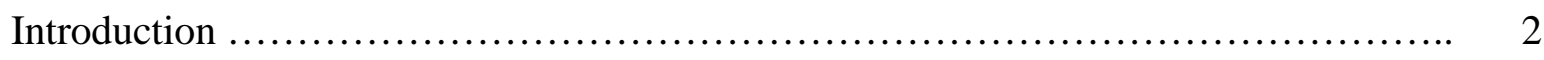

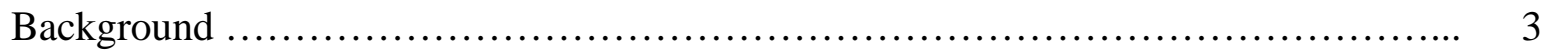

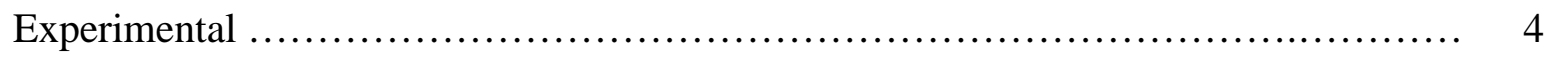

Process Limits................................................................. 9

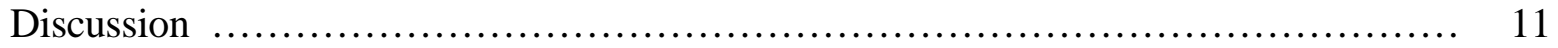

Conclusion .................................................................. 12

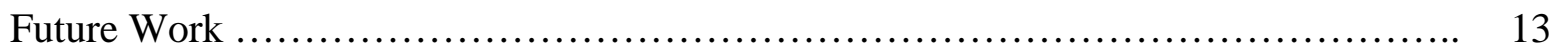

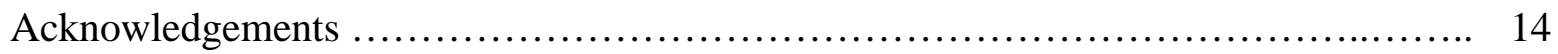

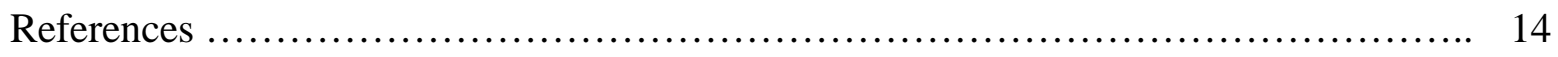

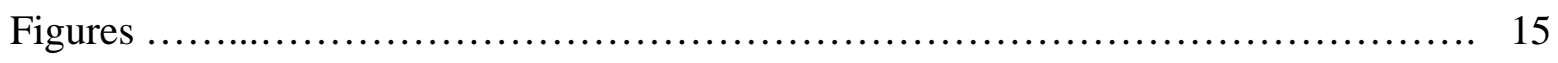

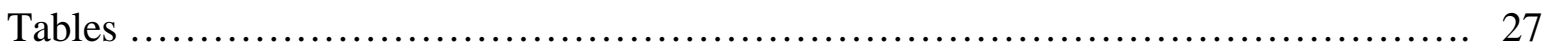




\title{
Keywords:
}

Plutonium Oxide, Powder, Direct Fabrication

\section{Development of the Direct Fabrication Process for Plutonium Immobilization (U)}

\author{
J. W. Congdon, K. M. Marshall
}

\section{Executive Summary}

The current baseline process for fabricating pucks for the Plutonium Immobilization Program (PIP) includes granulation of the milled feed prior to compaction. A direct fabrication process was demonstrated that eliminates the need for granulation. Feed preparation methods were developed and organic additives were selected to produce a milled feed that could be pressed and sintered to form high-density pucks acceptable for disposal in a repository. The critical process variables were optimized and the process limits for these variables were established. It was also demonstrated that by adjusting the sintering schedule, direct fabrication could produce good quality pucks from feeds containing impurities expected to be encountered in the immobilization process.

A method was also demonstrated to transfer weighed charges of the milled powder into the die cavity of the press. The milled feed was discharged from a weight-loss screw feeder to a feed tube and through the wall of an extension to the die cavity. This method was proven to be very effective at containing the dust during transfer of the feed to the press.

The direct fabrication process offers many advantages over the baseline granulation process. The most obvious advantage of implementing this process would be the removal of a major process step. This would eliminate the cost, operation, and maintenance of granulation equipment. Because direct fabrication is a dry process, accountability and criticality concerns associated with adding water during granulation would be eliminated. Furthermore, a cooling period between the granulation and compaction step would no longer be needed, eliminating a significant process variable as the granulated feed can lose moisture during storage. Without the granulation step, the feed handling process would no longer include a need to make and break connections during transfer of feed in and out of the granulator, a potentially major source of dusting in the glove boxes. Most importantly, the elimination of granulation would reduce the radiation exposure to personnel and reduce the potential for contamination problems. 
Although many of the challenges for developing a direct fabrication process for plutonium immobilization have been resolved, the process must be demonstrated with production-scale equipment, with the full range of impurity compositions, and with actinide materials.

\section{Introduction}

Approximately 13 metric tons of excess plutonium will be immobilized in titanate-based ceramic pucks. ${ }^{1}$ The pucks will contain $9.5 \mathrm{wt} . \%$ plutonium in a pyrochlore crystalline structure. The plutonium feed includes significant concentrations of uranium and other impurities that can affect sintering behavior and phase formation in sintered pucks. The sintered pucks will be placed into steel cans ( 20 pucks/can) and the cans will be placed into large canisters that will be filled with highly radioactive waste glass in the Defense Waste Processing Facility (DWPF). ${ }^{2}$

The baseline fabrication process to produce pucks is a cold press / sinter process that currently requires granulation of the milled powder prior to compaction. Granulation improves the flow characteristics of the feed and reduces the dusting during transfer of the feed to the die cavity. In addition, granulation is often required in ceramic fabrication processes to achieve high densities since fine, non-plastic powders are difficult to compact.

As in any nuclear facility, it is desirable to simplify the process as much as possible to reduce the capital and operating cost. It is even more important to reduce the potential for radiation exposure and contamination. These were the primary incentives for developing a fabrication process that did not require granulation.

The elimination of granulation would simplify the fabrication process and results in cost savings and other benefits to the plant. Direct fabrication would eliminate the costs associated with purchasing and installing a granulator in a glove box. Cost savings would also realized with a reduction in space required for the plant. Maintenance requirements would be reduced, resulting in less occupational radiation exposure to employees, in line with As Low As Reasonably Achievable (ALARA) principles. Lastly, direct fabrication eliminates water usage during granulation. The baseline granulation process is the only unit operation in the process that requires the addition of water to the feed material. With no water addition, criticality concerns would be reduced and tracking of fissile mass would be less complicated.

In order to demonstrate the feasibility of the direct fabrication process, the following tasks had to be completed: (1) selection of a binder and determination of the amount of binder required to produce good quality pucks; (2) development of a procedure to add the binder prior to milling; (3) development of a method to charge the die with milled powder (this method had to minimize dusting to the glove box as the die is being charged); and (4) demonstration that the green strength of the pucks was adequate for remote handling. This report discusses the progress that has been made to develop and 
demonstrate these criteria.

In addition to the four tasks described, additional testing will be required to evaluate the effects of impurities on the sintering behavior of pucks produced by the direct fabrication process. Full-scale demonstrations of the baseline process and the direct fabrication process will be performed in the Ceramic Prototype Testing Facility (CPTF) that is being constructed at the Clemson Environmental Technologies Laboratory (CETL). ${ }^{3}$ The facility will be a production-scale ceramic processing line consisting of prototypic equipment, with the testing limited to surrogates. Full-scale testing with actinides will be the final requirement for completion of the process demonstration.

\section{Background}

During the first half of 1999 the process development work at the CETL was focused on using a roll compactor to granulate the milled feed prior to compaction. It was demonstrated that high-density pellets could be produced from roll compacted granules without any cracking problems. ${ }^{4}$ The roll compactor was considered too complex to maintain in containment due to the number of rotating shafts and wear on parts. Several other granulation processes were evaluated at LLNL. These included a pin mixer, a fluidized-bed granulator, a blade mixer with liquid injection, and a tumble mixer with liquid injection. It was demonstrated that most of these granulation methods produced feed that could be compacted and sintered to form acceptable pucks.

A double cone blender with a liquid injection system was selected as the baseline granulation process. Most of the development work with this granulation system was performed at LLNL. In this process, up to $10 \mathrm{wt} . \%$ of a mixture of water and organic additives is added to milled powder during tumbling to form granules. This granulation process improves the flowability of the feed and reduces dusting. These properties are important for feed handling and during compaction. The surface water added to the feed during granulation acts as a lubricant and aids in compaction.

Although granulation improves the handling and compaction behavior of the feed, the operation and maintenance of the granulator present significant challenges, particularly for processing radioactive materials. Direct connections cannot be made to the processing vessel for feed transfers because the vessel must be free to rotate during the granulation process. Therefore, containment must be broken to transfer milled powder to the vessel and to remove the granulated feed. Fine radioactive particles would be lost to the glove box during these material transfers. Dusting in the glove boxes would create several potential problems including an increase in radiation exposure, an increase in the potential for contamination, shortened lifetimes for filters, and difficulty in accountability of radioactive materials. Since the milling process will increase the temperature of the feed to about $73^{\circ} \mathrm{C},{ }^{\mathbf{5}}$ the feed would need to be cooled for at least two to three hours prior to granulation. This would increase the processing time required to prepare the feed for compaction. The addition of water not only increases criticality and accountability concerns, it also causes operational problems. The water/binder inlet nozzle is very fine 
and can plug in between runs. As moisture accumulates on the interior of the vessel, the feed can cake on the walls of the vessel and hold-up could become a concern. Manual clean up would require a break in containment and radiation exposure to personnel.

The fabrication of relatively large compacts such as the pucks from very fine powder also presents several challenges. The baseline method of charging the die is not acceptable due to the poor flow properties of the milled feed and dusting concerns. Fine powders are very difficult to press into a uniform compact. Milled powders have very poor flow characteristics due to the high interparticle friction between the fine, angular particles. In addition, the milled powder has a low packing density that leads to problems created by entrapped air during compaction. Poor flow properties and entrapped air cause density gradients and laminations to form in green compacts. Green pucks must have a fairly uniform density to prevent cracking problems from differential sintering stresses. The pucks are formed from an intimate mixture of oxides. The sintering process is not the diffusion-controlled process typically used to densify ceramics, but rather a reactive sintering process in which the mixture of oxides reacts to form several phases. This reactive sintering process results in relatively large shrinkages.

It is this reactive sintering mechanism and high shrinkage that makes the direct fabrication process possible. Pucks can be formed at relatively low pressing pressures to form low-density compacts. At these low compaction pressures the density variations in the green compacts are minimized. Sufficient binder is necessary to obtain the green strength required for remote handling. The reactive sintering yields high-density pucks despite the relatively low density of the green puck.

Experiments performed at the CETL in July 1999 demonstrated the possibility of fabricating pucks directly from milled feed. Additional experiments have been performed to study the effects of feed preparation variables, to optimize the type and content of the organic additives, and to develop compaction and sintering parameters. Tests were also performed to establish process limits for the critical process variables.

As part of the process development, a method was demonstrated to transfer milled feed into the die cavity. Several concepts based on using a screw feeder to charge the die were designed, fabricated, and tested. The design was optimized to contain the dust, to produce a consistent charge to the die, and to minimize the impact on the current press design.

\section{Experimental}

Equipment: The equipment used in this development work was laboratory-scale equipment. Although small in scale, the batches were sufficient ly large to make fullscale pucks. The equipment is described in the appropriate sections. Based on limited testing with production-scale equipment at LLNL and at vendor test facilities, no significant scale-up problems are anticipated. 
Quality Assurance: Weights and measurements were obtained with calibrated balances and calipers. The accuracy of both the thermocouples and compaction pressures was functionally verified. Logbooks were maintained to document the usage of the primary process equipment (mill, press, and furnace) and measuring devices (balances, moisture meter, calipers, and micrometers). Puck and experimental data were recorded on data sheets and in laboratory notebooks. Since the results of these studies will not directly impact the plant operations, the experiments were considered as scoping activities. The Task Technical and QA Plan ${ }^{6}$ documents the QA requirements of the work presented in this report.

Process Flowsheet: The flowsheet that was developed for the direct fabrication process is presented in Figure 1. The details and recommended parameters for each step are described below. With the baseline surrogate composition, this flowsheet consistently produced high density (94 to 95\% theoretical density), crack-free pucks as shown in Figure 2.

Precursor Mixing: After weighing, the precursors were slowly added to water. The slurry was stirred using an impeller mixer during precursor addition and for an additional twenty minutes after precursor addition. Batch sizes varied from $\sim 700 \mathrm{~g}$ to $\sim 5.6 \mathrm{~kg}$. The slurries contained $44 \mathrm{wt} . \%$ solids. The slurries were poured into stainless steel drying pans to a depth of 2 to $4 \mathrm{~cm}$. "Best mixing practices" were used to size the containers, position the impeller, and set the mixing speed.

Precursor Drying: The slurries were dried overnight at $100^{\circ} \mathrm{C}$. This resulted in dried cake that cracked and shrunk away from the walls of the pan. These drying conditions were not evaluated as critical process variables.

Comminution of Dried Cake: The large chunks of dried cakes were broken-up and sized to produce a free-flowing feed that could easily be poured into the calcination trays and then fed to the attritor mill. In the initial testing, this procedure was performed with rotating bars rasping against a fine-mesh screen. The wear and failure rate of the screens was quite high. In later tests, a Quadro Comil ${ }^{\circledR}$, Model $197 \mathrm{~S}$ was used. This mill used a rotating bar to force the dried cakes through a perforated steel cone. No significant wear was observed on the perforated plates. Screens and plates with various sized holes up to $3 \mathrm{~mm}$ (3000microns) were evaluated. A hole size of 910 microns was selected as the baseline since it produced a free flowing feed with minimal dusting.

Precursor Calcination: The ground precursors were placed into aluminum oxide trays for calcination. The bed depth was limited to less than $4 \mathrm{~cm}$ to minimize temperature gradients in the feed. Calcination was performed in static air. The furnace was heated at $300^{\circ} \mathrm{C} / \mathrm{h}$ to $750^{\circ} \mathrm{C}$. After a one-hour dwell time at $750^{\circ} \mathrm{C}$ the furnace was cooled at $300^{\circ} \mathrm{C} / \mathrm{h}$ to room temperature. The actual cooling rate was slower due the lack of cooling for the furnace and the high heat capacity of the trays and feed.

${ }^{\circledR}$ Quadro Comil, manufactured by Quadro Engineering Inc., Waterloo, Ontario, Canada 
Ceria Calcination: Ceria was used as a surrogate for both uranium oxide and plutonium oxide. The actinide oxide feeds for the production process will be high fired. Heating the ceria powder in static air to $1000^{\circ} \mathrm{C}$ with a one-hour dwell time simulated the baseline process. The heating and cooling rates were $300^{\circ} \mathrm{C} / \mathrm{h}$.

Binder Addition: The organic binders were added to the feed prior to milling. Duramax ${ }^{\circledR}$ binders in the form of colloidal aqueous suspensions were used. The binders were thoroughly mixed with the precursors by wet mixing. Critical mixing parameters such as batch size, slurry viscosity, mixing speed, mixing time, the type of mixing blade, stirrer position, and size of the mixing container were optimized.

Fabrication tests were performed to evaluate the effectiveness of a variety of binders, various combinations of binders mixed in different ratios, and binder content. Most of the binder testing was performed with Duramax acrylic resin binders (B-1020, B-1043, \& B-1070), polyethylene glycol (PEG 8000 and PEG 20M), hydroxypropyl methylcellulose (HPMC), and polyvinyl alcohol (PVA). The total binder content was commonly in the 2 to $6 \mathrm{wt}$.\% range. Binder mixture ratios of 1:1 to 4:1 were tested. In preliminary screening tests, pucks fabricated with PEG, PVA, and HPMC or combinations of these binders cracked during sintering. Additional development work with these binders may have been successful.

It was determined that the optimum binder system was a mixture of Duramax binders (1 wt.\% B-1020 \& 3 wt.\% B-1070). It should be noted that the Duramax binders were colloidal suspensions and the weight percent requirements are for the solids portion of the suspensions. These binders were blended with the calcined precursors by wet mixing a $39 \mathrm{wt} . \%$ slurry of precursors using a $0.25 \mathrm{hp} \mathrm{impeller} \mathrm{mixer} \mathrm{operated} \mathrm{at} \mathrm{approximately}$ 20-40 rpm. The inner diameter of the mixing pail was 9.5 inches, the blade was 6 inches in diameter, and the shaft was angled at about 23 degrees off vertical.

Slurry Drying: The slurry of precursors were dried to reduce the moisture content to prevent the feed from caking in the attritor mill. The slurry was dried at $100^{\circ} \mathrm{C}$ for approximately 48 hours to reduce the moisture content to $<1.5 \mathrm{wt} . \%$ prior to milling.

Comminution of Dried Cake: The dried cakes were broken up and sized in the Quadro $\mathrm{Comil}^{\circledR}$ to produce a free-flowing feed. The optimum hole size of 910 microns produced feed with a maximum diameter of $\sim 500$ microns.

Preblending: The high fired ceria and precursors were blended with a grinding aid prior to milling. One-kilogram batches of this feed were loaded into a one-gallon jar that was shaken with a Turbula ${ }^{\circledR}$ mixer at medium speed for 20 minutes. It was shown that both Acrawax $\mathrm{C}^{\circledR}(0.75$ wt. $\%)$ and ACumist $^{\circledR}(1.0$ wt.\%) were effective grinding aids.

\footnotetext{
${ }^{\circledR}$ Duramax is a trademark of Rohm \& Haas Company, Philadelphia, PA

${ }^{\circledR}$ Turbula System Shatz, Willy A. Bachofen AG Maschinefabrik, Basel, Switzerland

${ }^{\circledR}$ Acrawax C lubricant by LONZA, Fairlawn, NJ
} 
These organic compounds absorb excess surface moisture from the feed material to help prevent caking problems in the mill. Although this preblending process was used throughout this development program, recent tests indicate that it will not be required for the production process (i.e. the precursor and actinide feed could be directly fed to the attritor mill for mixing and grinding). As with the other organic additives, the grinding aid decomposed during sintering.

Milling / Mixing: The calcined precursors and binder were mixed and milled with the calcined ceria in a high-speed attritor mill (Szegvari Attritor System ${ }^{\circledR}$, HSA-1). The milling procedure was identical to that used in the baseline process. The milling time was five minutes at high speed (1000 rpm in a one-gallon mill). As with any feed, the cooling of the mill had to be controlled. Excessive cooling, particularly with the mill open to the atmosphere, caused condensation on the walls of the mill. This condensation caused caking of the feed powder. High milling temperatures (insufficient cooling) also caused caking by softening or melting the organic additives.

Feed System and Die Charging: Free-flowing feeds, such as granulated feed, can be charged using a shoe type feeder that relies on a consistent volumetric charge to uniformly fill the die cavity. The poor flow properties of fine powders were expected to prohibit the use of a shoe feeder. Testing with the LLNL system confirmed this, as some of the charge weights were inconsistent. Dusting problems with the shoe feeder system also increased with milled powder.

Several feed system designs were considered. Vibratory feeders did not appear to be an acceptable option. The milled feed flooded the vibratory feeder and overflowed the feed trough. A screw feeder was selected as the best device to transfer the charge from a hopper to the die cavity. Volumetric screw feeders were evaluated. The screw speed and discharge time could be controlled, but the feed rate was dependent on the quantity or height of material in the hopper that feeds the screw.

Weight-loss screw feeders are commercially available to precisely meter the required quantity of feed into the die. Testing with a weight-loss screw feeder confirmed that it was the best option. Tests demonstrated that a 500 gram charge could be fed in $~ 30$ seconds. This feeding time was well within the time required to satisfy PIP production rates.

One issue encountered in using the screw feeder was that the powder formed an uneven charge in the die cavity that could be difficult to compact uniformly. This potential problem was averted by applying a minor mechanical disturbance to the die cavity after feeding, leveling the feed. In the plant, a small movement of the bottom ram could accomplish this leveling effect. This could easily be designed into the production press.

\footnotetext{
${ }^{\circledR}$ Acumist by Allied Signal Inc, Morristown, NJ

${ }^{\circledR}$ HSA-1 by Union Process, Akron, OH
} 
The feed tests with milled powder have led to the development of feed system based on a weight loss screw feeder. The CPTF feeder will be equipped with a slam-gate valve that will seal the end of the screw feeder after a fixed weight of powder has been discharged. This valve will prevent additional powder from discharging as the feed is pressed and the pellet is removed. The powder discharged from the feeder will flow down a feed tube that will be connected to the feed adapter above the die cavity. The die assembly will include a port off of the feed chamber allowing connection of a vacuum purge to a HEPA filter system. Development work has demonstrated that a slight vacuum purge helps to control dusting as the feed is charged. It has also been shown that the vacuum can be maintained during compaction to reduce dusting from around the punches. The CPTF press will have sufficient stroke to press and eject pucks through the feed adapter above the die cavity. The feed adapter will have a slightly larger diameter than the die cavity to allow for the elastic expansion of the green puck as it is ejected past the feed port.

Compaction: The pucks were formed by compaction at a pressure of 1,560 psi $(15,000 \mathrm{lb}$ load). The green strength of the pucks was sufficient for remote handling by a robotic puck handler. In addition to compaction pressure, the compaction rate was a critical variable. Development work was performed with 30-ton Carver hydraulic presses. The spring-loaded die assembly, shown in Figure 3, simulated double-action compaction. The compaction rate on these presses was controlled through the setting of the pump speed. The loading and linear compaction rates were not constant as the pucks were pressed.

The low packing density of the milled feed resulted in a significant volume of air trapped as the feed compacted. The air had to be expelled between the die wall and punches during compaction to allow for the particles to rearrange without causing density gradients and cracking. The tight tolerances between the punches and die wall limited the removal of this air. As shown in Figures 4 and 5, cone-capping and lamination cracks were caused by entrapped air when the feed was compacted at excessive rates (pump speed $>20 \%$ of the maximum speed with standard die design) or at excessive pressures (>2000 psi). Cone-capping occasionally caused fracture of the green pucks as they were removed from the die. Although these defects formed during compaction, often they were not evident until after sintering. It was demonstrated that reducing the compaction rate reduced the frequency of these defects. This allowed time for the air to escape without causing defects during compaction. It was also demonstrated that the design of the bottom punch could be modified to improve the release of air during compaction. Vertical grooves were machined in the sidewalls of the punches to within $1 / 16$ " of the punch face and most of the length of the punch was left open by using an open cross design to position the punch. A bottom punch with these modifications is shown in Figure 6. These modifications eliminated lamination and cone-capping at pump speeds up to $25 \%$ of the maximum speed.

Sintering: The pucks were sintered on reticulated zirconia with an air purge. A continuous air purge of 30 to $50 \mathrm{SCFH}$ was used during these tests. A conservative heating cycle of $3^{\circ} \mathrm{C} / \mathrm{min}$ to $300^{\circ} \mathrm{C}$, $1 \mathrm{~h}$ hold, $4^{\circ} \mathrm{C} / \mathrm{min}$ to $1350^{\circ} \mathrm{C}$, 4-hour hold, and cooling at $5^{\circ} \mathrm{C} / \mathrm{min}$ produced good quality pucks. Most of the tests were performed in a small CM furnace using this heating cycle, however, process limit tests indicated that 
faster heating rates $\left(5^{\circ} \mathrm{C} / \mathrm{min}\right)$ could be used for pucks with the baseline composition. The heating cycle may need to be adjusted in the production furnace to accommodate the higher organic loading and temperature differentials in the larger mass of materials that includes trays and pucks.

Impurity Effects: Tests were performed to evaluate the effect of impurities on the ability to process feed and fabric ate pucks using the direct fabrication process. Two different impurity compositions, identified as A-9 and B3-13, were used in these tests.

The composition A-9 originated from the Glass Team prior to the PIP immobilization form down select. The impurities were estimated for the $50 \mathrm{MT}$ case and added to the glass composition at $2 \mathrm{X}$ the calculated composition. This composition was also used by the Ceramic Team to provide continuity between the compositions tested. The nonradioactive composition was calculated by replacing the plutonium and uranium with cerium on a molar basis. In addition, the original A-9 was based on a $10 \mathrm{wt} . \%$ plutonium loading. In the past year the plutonium content of the form was reduced to $9.5 \mathrm{wt} \%$. The A-9 composition is shown in Table 1.

The composition B3-13 was part of one of a series of several impurity categories developed to determine the amount of impurities that could be accommodated in the ceramic form. The B3 series, "Process and Compositional Extremes," evaluated several "average" and "worst case" compositional scenarios. Based on the 50MT case, B3-13 was the average of each of the impurities from all of the plutonium feed streams. As with the A-9 composition, the non-radioactive composition was calculated by replacing the plutonium and uranium with cerium on a molar basis. The original B3-13 was based on a 10 wt.\% plutonium loading. The B3-13 composition is shown in Table 2.

Tests were performed to determine the effect of the A-9 and B3-13 impurities on pucks produced by the direct fabrication process. Additional tests were then performed to determine if process conditions could be adjusted to mitigate the detrimental effects of impurities.

\section{Process Limits}

Tests were performed to define the process limits for the critical process variables. These tests provided a better understanding of the effect that the variables had on the quality of the pucks. Additional testing will be required in the CPTF to determine the process limits of production-scale equipment. The limits will be used to define how plant operations will be controlled. In addition, these limits will provide a basis for equipment specifications.

Comminution: Testing with the attritor mill indicated that off-normal conditions could cause the feed to form a cement-like material that was very difficult to remove. With radioactive feed material, cleaning the mill would be difficult and also hazardous. 
At higher binder concentrations (6 wt.\%) or higher moisture content (>1.5 wt.\%) the feed caked in the mill and would not discharge. To prevent caking in the mill, the moisture content of the feed must be $<1.5 \mathrm{wt} . \%$, the Duramax concentration must not exceed 6 wt.\%, and at least 0.5 wt.\% Acrawax must be added to the feed. Limited testing with impurity compositions suggested that even lower moisture contents might be required with impurities.

Compaction: Pucks with acceptable green strengths could be produced at compaction loads of 10,000 to 30,000 lbs. The frequency of lamination cracking and cone-capping increased with increased loads. Pump speeds of up to $35 \%$ were tested. The frequency of lamination cracking and cone-capping increased as the pump speed increased.

Using the slotted bottom punch, a load of $15,000 \mathrm{lbs}$ or less, and a pump speed of $25 \%$ or less, no cracking was observed in the green or sintered pucks fabricated from the baseline feed material.

Sintering: The cycle time of the furnace is critical for the plant design since it controls the throughput. Therefore, the number of furnaces required for the plant will be a function of the required throughput (156 pucks/day), the furnace capacity (54 pucks), and the cycle time (TBD). It is obviously desirable to shorten the cycle time as much as possible. Tests indicated that the initial heating rate to $300^{\circ} \mathrm{C}$ could be increased to $5^{\circ} \mathrm{C} / \mathrm{min}$. Attempts to shorten the hold time at $300^{\circ} \mathrm{C}$ to 0.5 hour or to completely eliminate the hold were unsuccessful. Higher initial sintering rates or elimination of the $300^{\circ} \mathrm{C}$ hold caused cracking or sometimes an eruption in the top of the puck (Figure 7) as the off-gas products pressurized the puck. In the tests, all of the pucks with a decreased hold period cracked. A longer hold time ( 2 hours) did not have a significant effect on the sintered pucks, however, sintering in the production furnace may require a longer hold time to allow the temperature in the furnace to equilibrate.

During the initial stage of sintering, the furnace must be purged with air to remove the organic decomposition products. Current plans are to purge the production furnace only during the initial stage of sintering. Sintering development work was performed in a small box furnace that required a purge throughout the cycle to cool the connections to the heating elements. This development work indicated that the purge rate was a critical parameter. The airflow must be sufficient to remove the organic decomposition products and maintain an oxidizing atmosphere. In the small box furnace, the optimum purge rate was $30 \mathrm{SCFH}$ with two pucks. The pucks cracked during sintering when the purge rate was reduced to $20 \mathrm{SCFH}$. It was also shown that increasing the purge rate to $100 \mathrm{SCFH}$ caused the pucks to crack. It appears that the increased flow rate of room temperature air created a temperature gradient across the pucks during sintering. These temperature differences apparently caused differential sintering stresses that were sufficient to cause cracking. In both the low and high purge rate conditions, radial cracks initiated from the circumference of the pucks as shown in Figure 8.

Impurities: Impurities in the plutonium-surrogate feed often caused the pucks to crack and swell during sintering. As shown in Figure 9 and 10, the severity of the cracking 
problem varied with the composition of impurities. Impurities also affected the feed preparation conditions. In particular, the amount of grinding aid had to be increased in batches with high concentrations of impurities. Based on these observations, the type and concentration of impurities are expected to be a critical factor in determining feed and process parameters.

Preliminary tests were performed to evaluate the effect of impurities on pucks produced by the direct fabrication process and to determine if adjusting the process conditions could mitigate detrimental effects. It was demonstrated that significant improvements in the quality of the pucks with impurities could be realized by decreasing the heating rate to $3^{\circ} \mathrm{C} /$ minute for the entire heating cycle and adding a one hour hold at $700^{\circ} \mathrm{C}$. As shown in Figures 11 and 12, this heating cycle was effective for both the A-9 and B3-13 impurity compositions. Although minor cracking was observed in these pucks, they were integral and within specifications for repository fitting into the can for disposition via the can-in-canister technology. The cracking appeared to have initiated from the bottom of the pucks and was attributed to amorphous impurity phases (glass) sticking to the reticulated zirconia setter during sintering. As the pucks were restricted from shrinking, the resulting stresses were apparently sufficient to cause cracking. Process limit tests confirmed that $700^{\circ} \mathrm{C}$ was the optimum hold temperature to mitigate cracking in the A-9 and B3-13 impurity compositions. Tests with one-hour holds at $600^{\circ} \mathrm{C}$ and $800^{\circ} \mathrm{C}$ were not as effective in mitigating cracking. Tests with a one-hour hold at $700^{\circ} \mathrm{C}$ but with higher heating rates of 4 or $5^{\circ} \mathrm{C} / \mathrm{min}$ also resulted in more cracking.

\section{Discussion}

Using an actinide surrogate and laboratory-scale equipment, the direct fabrication process has been demonstrated and process limits for the critical parameters have been established. The centerline processing parameters for the feed preparation process, compaction of milled feed, and sintering parameters have been well defined. More than 700 pucks were fabricated for this development program. Although a wide range of process conditions was tested, most of the pucks were within specifications for disposition via the can-in-canister technology. The process data for each batch of feed, fabrication data for each puck, and characterization data for each puck including a description of cracking or other defects were documented in CETL logbooks. User logs were also maintained for the electronic balances, calipers, and primary processing equipment. The conclusions presented in this report are based on fabrication tests that were at least duplicated and usually repeated several times to confirm the reproducibility of critical results. Hundreds of pucks were pressed and sintered to establish the baseline process. The centerline process parameters presented in this report were used in the making of more than 50 pucks and all were acceptable. Fewer pucks were made with the impurity compositions. The impurity test results should be considered as preliminary data. 
It does not appear that the transfer of the direct fabrication process to production will be a difficult task. Scale-up of several of the process steps has already been demonstrated. It has been established that the development equipment will consistently produce highdensity crack-free pucks at the optimized process parameters. In most cases, the production equipment should provide even better control and reproducibility of results.

In preparation for the CPTF operations, the feed preparation process steps including mixing, drying, and calcination have already been scaled-up successfully to produce production-sized batches. Additional testing will be required to determine if spray drying is an acceptable feed preparation method. Spray drying would simplify the process but is not required for the successful scale-up of direct fabrication.

The scale-up of the milling process has been demonstrated using 10-gallon attritor mills at LLNL and a 30-gallon attritor mill at Union Process ${ }^{6}$. The production process will use a 20-gallon mill.

The compaction of milled powder with an automatic production press will be demonstrated in the CPTF. The design and technique to charge milled powder to the die will be optimized in the CPTF. The initial compaction tests with the production press will be performed with standard punches, although their design may need to be modified to vent the entrapped air so that the milled feed can be compacted without causing lamination or cone-capping cracks.

It appears that binder burnout and sintering will be the most difficult portion of the process to scale-up for production. Process limit tests indicated that the purge rate and thermal cycle are critical process parameters that must be carefully controlled.

Preliminary tests with the CPTF production-scale furnace have shown that it is difficult to maintain a relatively uniform temperature throughout the height of the furnace as it is heated. The tests also indicated that the flow rate of air around a puck depends on its location in the furnace. The furnace was designed to prevent incoming air from impinging directly on the pucks, however, turbulence around the exhaust port caused pucks on the top tray to crack. Placing a cover over the pucks on the top tray solved this problem. Other modifications have improved the thermal equilibrium in the furnace such that good quality pucks can be produced at all positions in the furnace.

\section{Conclusions}

The development work described in this report indicates that direct fabrication is a viable process for the immobilization of plutonium oxide. It has been demonstrated that the difficulties associated with charging milled powder to a die and compacting it to form high-density, crack-free pucks can be overcome. High density crack-free pucks can be produced consistently from the baseline surrogate feed. Preliminary tests also indicate that modifying the heating cycle can mitigate the swelling and cracking problems associated with high impurity concentrations. 
Based on the expected precision of the production equipment and the process limits that have been determined for the operating parameters, it appears that direct fabrication could be implemented as a production process. Direct fabrication offers several important advantages over the baseline granulation process. It is recommended that the remaining development work on the direct fabrication process be completed expeditiously and, if these tests are successful, direct fabrication should be considered as the baseline process for all future testing and pilot-plant demonstrations.

\section{Future Work}

In the production process it would be desirable to add binders to the precursors by spray drying, however, this has not been successfully demonstrated for the direct fabrication process. Preliminary testing produced sintered pucks with radial cracks. Thermogravimetric analysis of the spray-dried feed confirmed that the binder content was acceptable. The cause of the cracking was not determined. Additional development work will be required to determine if spray dried feed can be used for the direct fabrication process.

Additional testing will be performed to determine the optimum process conditions and process limits with production scale equipment in the CPTF. The CPTF will include a weight-loss screw feeder with an adapter to charge the die with milled feed. The adapter will include a port for a vacuum purge to aid in dust control as the die is charged and as the powder is compacted. The stroke of the press will be sufficient to eject the puck through the adapter. The control of the compaction rate will be greatly improved with the automatic press. The automatic press will also provide true double-action compaction that is expected to reduce the density gradients in the green pucks.

The CETL is not currently equipped to perform actinide testing of the direct fabrication process. Limited testing with uranium oxide was planned at LLNL, but has now been cancelled. Because of this, it may be necessary to establish capability at the CETL to process uranium oxide. LLNL was also constructing a facility to demonstrate the process with plutonium. Although currently postponed indefinitely, this facility would not have the capability to remotely charge milled feed into the die. Testing of direct fabrication at this facility would need to be performed by manually charging the die with plutonium feed.

The actual plutonium feed for this process will contain significant quantities of impurities. Form development work has indicated that these impurities cause cracking and/or swelling of the pucks during sintering. Preliminary tests with surrogates and the direct fabrication process indicate that controlling processing conditions such as sintering rate can mitigate the effects of impurities on the quality of pucks. Additional testing with other impurity compositions and with actinide materials is needed to verify this effect and to determine the optimum sintering schedule for the expected range of compositions. Laboratory-scale tests have also indicated that impurities can affect feed processing. Batches with high impurity concentrations have caked in a one-gallon attritor mill in tests 
with the standard processing conditions. Additional drying and grinding aid additions were required to prevent caking. Further evaluation of the effects of impurities on the direct fabrication process will be performed in the CPTF using production-scale equipment. Similar testing with granulated feed will provide a comparison of the effect of impurities on these process options.

\section{Acknowledgements}

We would like to acknowledge Carl Rathz for his outstanding effort in performing the experimental work at the CETL. Two Clemson University students, James Dean and Jonathan Latta assisted Carl in the preparation of feed. We would also like to thank several co-op students including Jennifer Hood (Clemson University), Justin Lee (Mississippi State), Kevin Socha (Georgia Tech), and Greg Goff (Clemson University/ORISE) for their assistance and enthusiasm. We are grateful to Clemson University, the CETL staff, and particularly Donald Erich (CETL Director) for their cooperation in this effort through the South Carolina Universities Research and Educational Foundation (SCUREF) program.

\section{References}

1. Fissile Materials Storage and Disposition Programmatic Environmental Impact Statement Record of Decision, Storage and Disposition Final PEIS, January 14, 1997, 62 Federal Register 3014.

2. N. H. Kuehn III, JR. Brault, D. T. Herman, M. J. Plodinec, M. K. Andrews, J. T. Coughlin, Poh-Sang Lam, and W. G. Ramsey, "Can-In-Canister Demonstration at DWPF, Radwaste Magazine, May 1997.

3. K. M. Marshall and J. W. Congdon, "Development of the Ceramic Prototype Test Facility - A Pilot Plant for Plutonium (Simulant) Immobilization, presented at the AChE Conference and published in the Proceedings, April 2001.

4. K. M. Marshall and J. W. Congdon, "A Process for Immobilizing Plutonium", presented at the ACerS Conference and published in the Proceedings, April 1998.

5. K. M. Marshall, A. R. Jurgensen, D. M. Missimer, J. W. Congdon, C. L. Rathz, "Performance Comparison between a One-Gallon and Thirty-Gallon Grinding Mill, for the Plutonium Immobilization Program," WSRC-TR-2000-00225, Rev. 0, issued August 31, 2000.

6. C. C. Herman, "Ceramic Prototype Test Facility - Task Technical \& QA Plan", WSRC-RP-200030, Rev. 1, issued January 18, 2001. 
WSRC-TR-2001-00283

Figure 1: Direct Fabrication Process Flowsheet

Revision 0

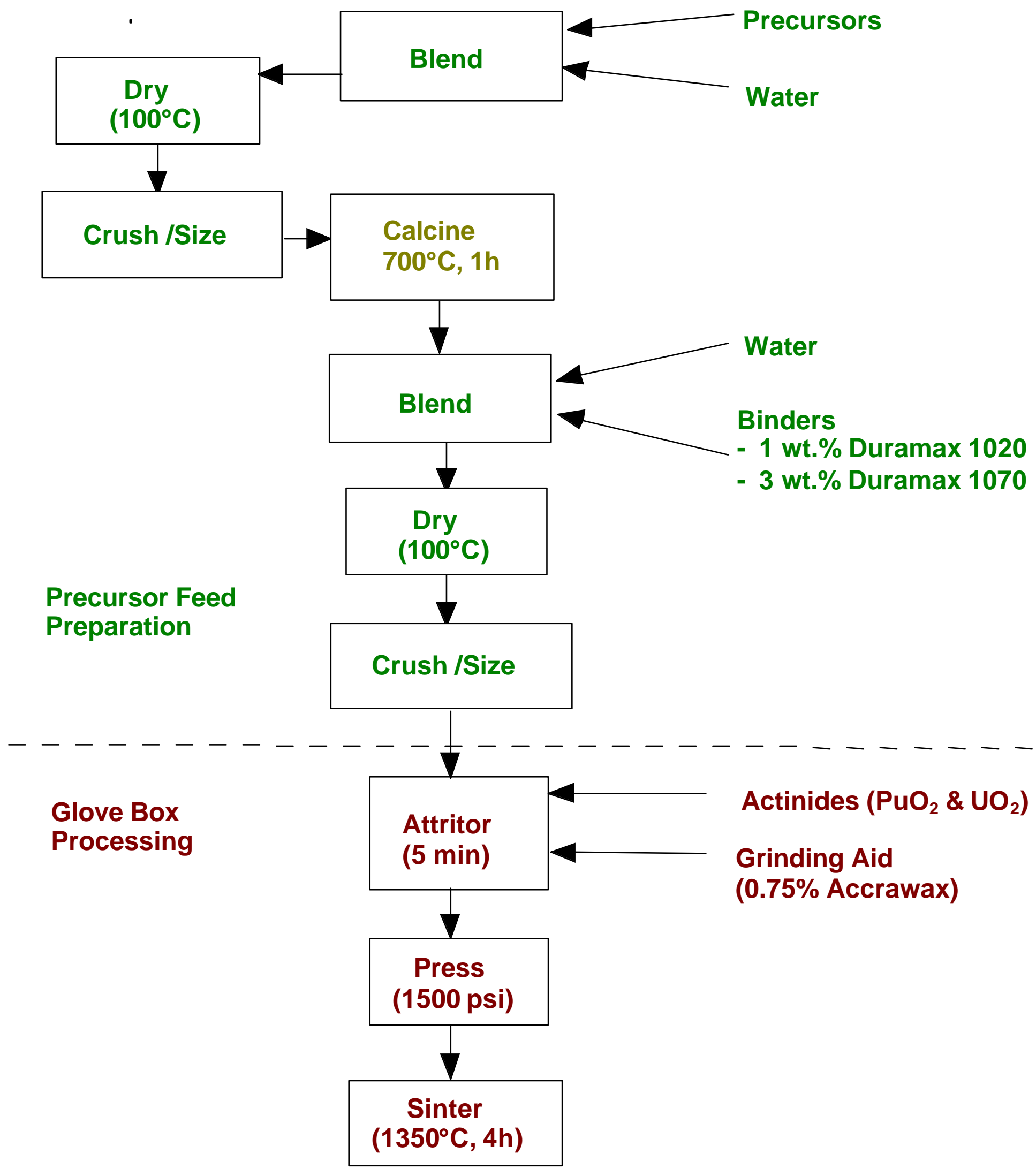


WSRC-TR-2001-00283

Revision 0

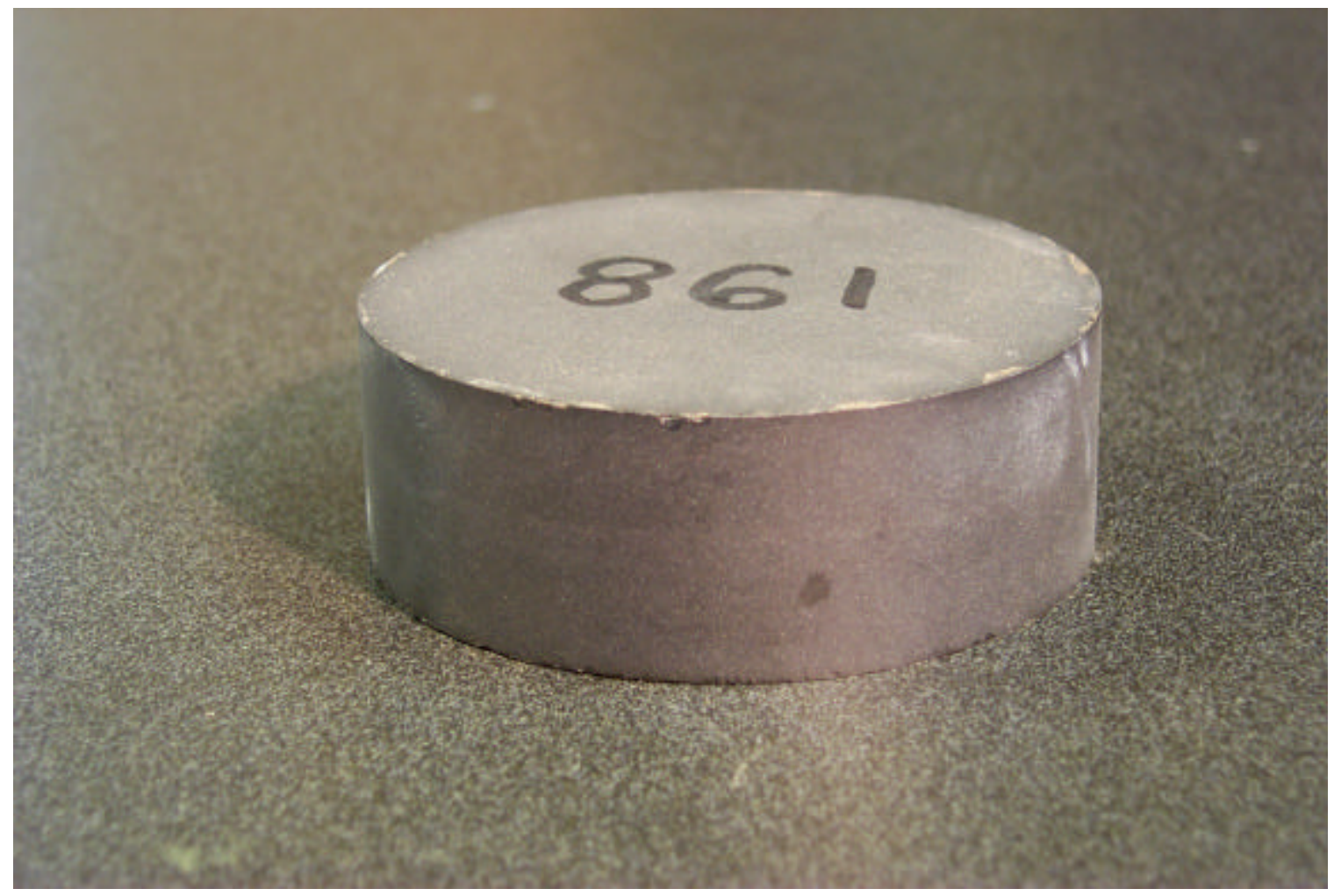

Figure 2: Baseline surrogate composition puck processed with centerline direct fabrication parameters. 
WSRC-TR-2001-00283

Revision 0

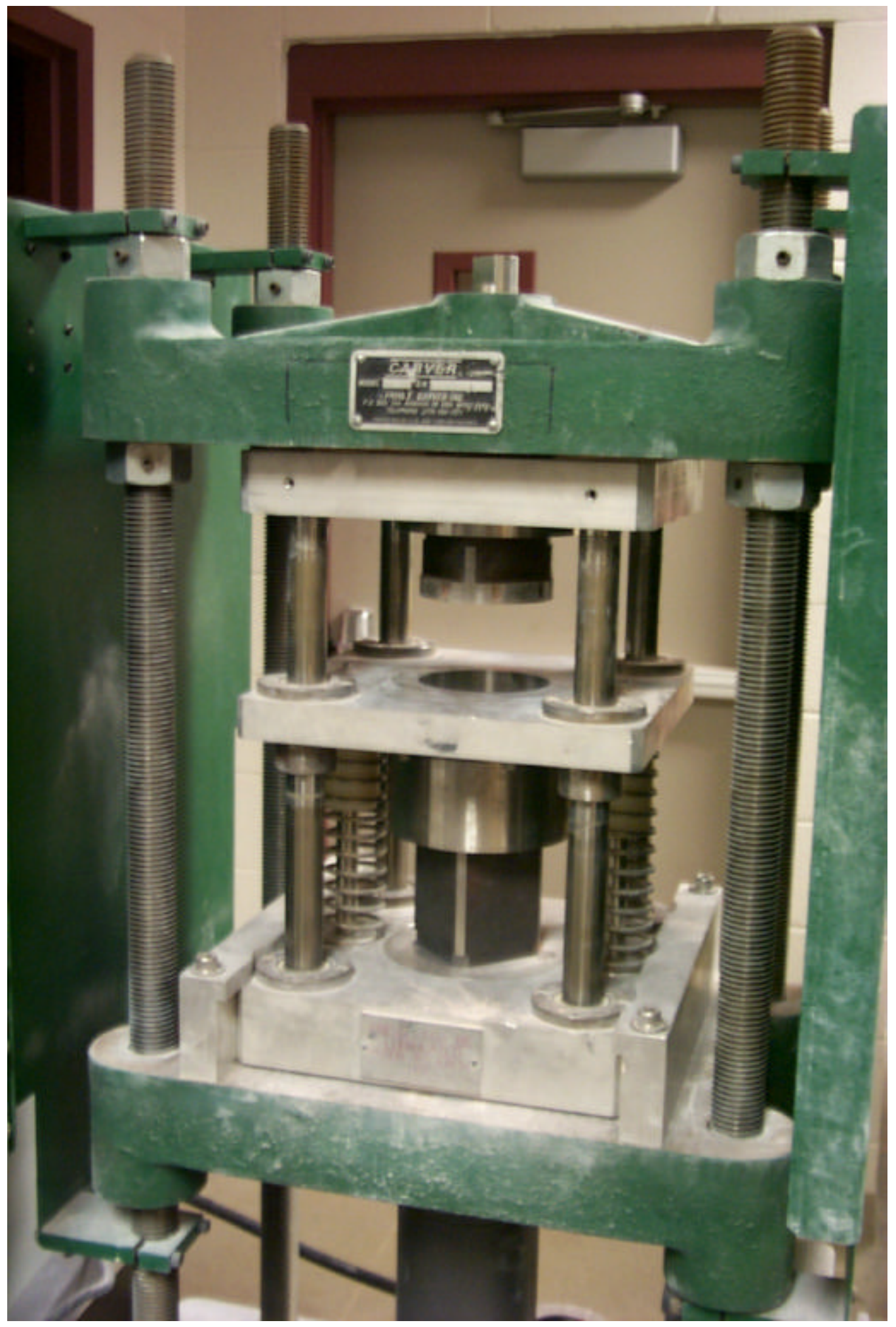

Figure 3: Double-action die assembly mounted in 30-ton press. 
WSRC-TR-2001-00283

Revision 0

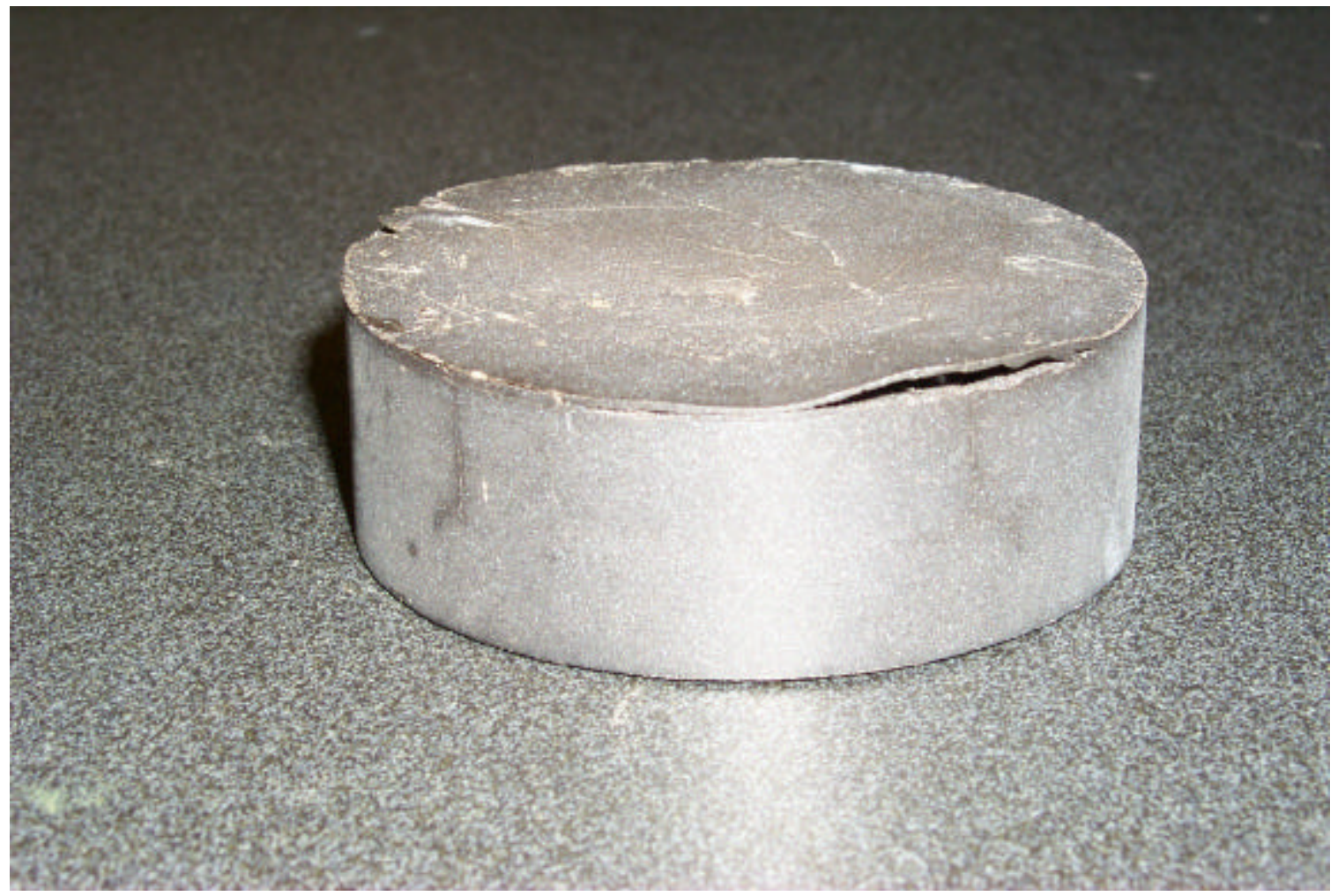

Figure 4: Cone-capped sintered puck compacted in die assembly without vented punches. 
WSRC-TR-2001-00283

Revision 0

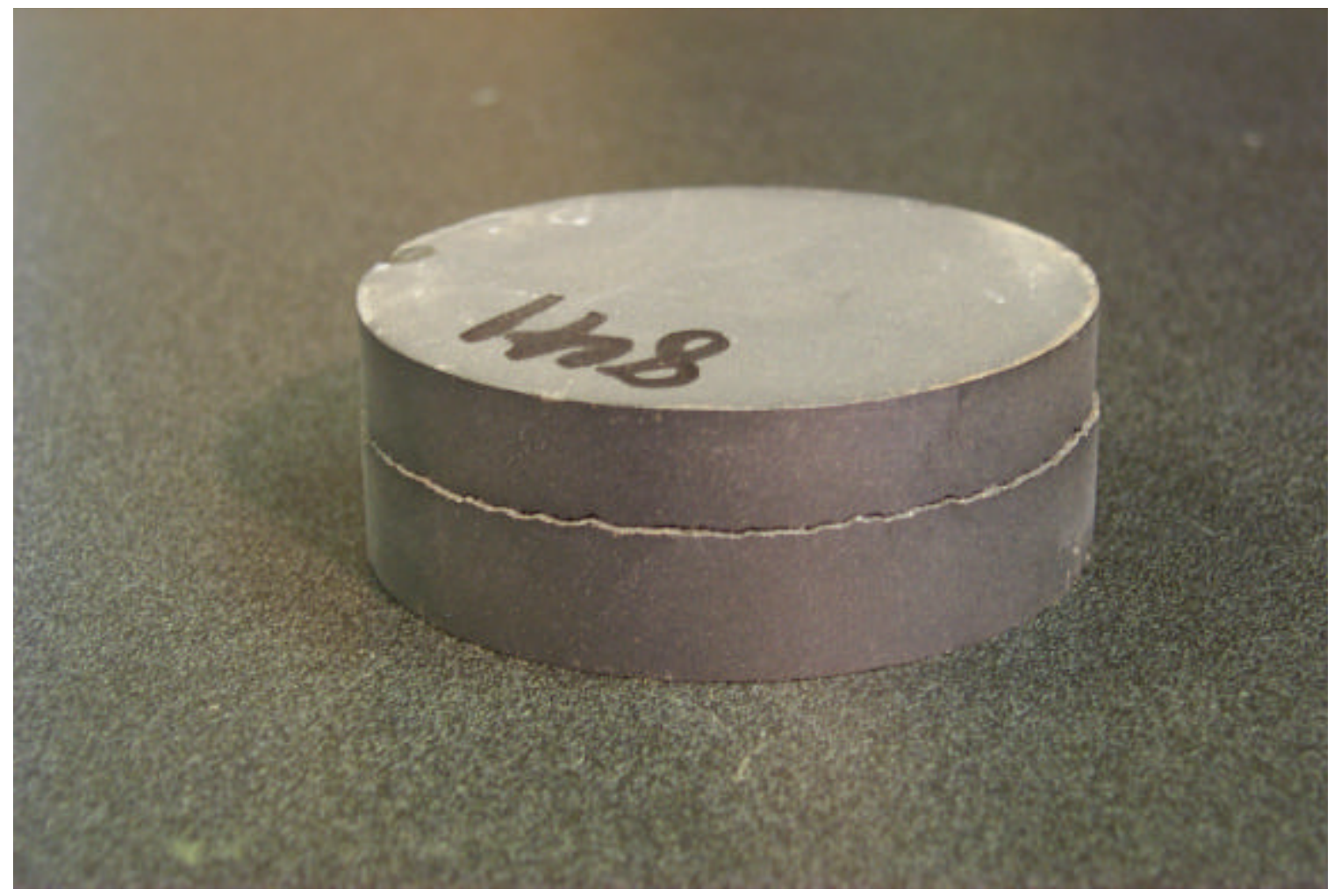

Figure 5: An excessive compaction pressure or excessive compaction rate can cause lamination cracks in sintered pucks. 
WSRC-TR-2001-00283

Revision 0

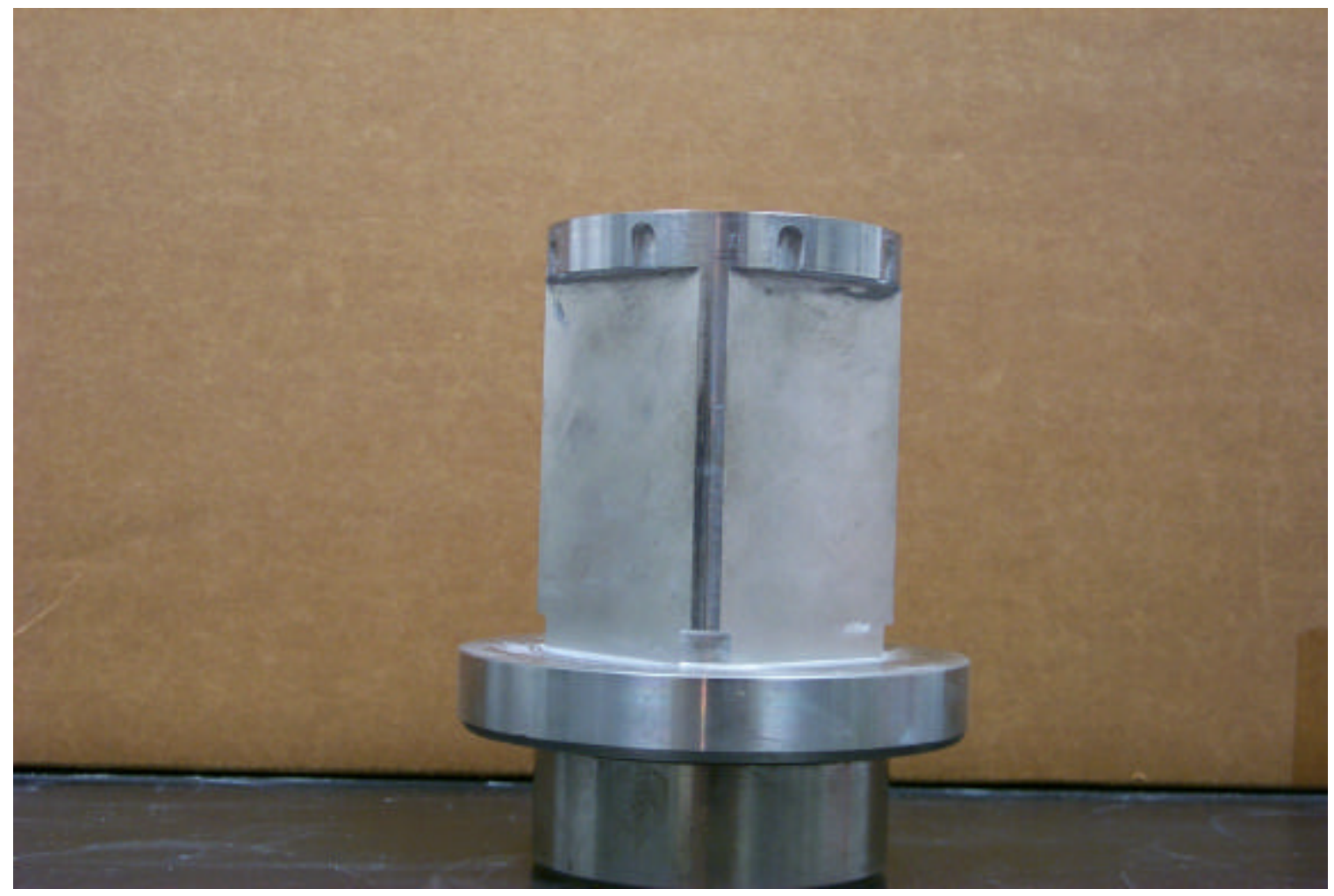

Figure 6: Bottom punch modified to vent entrapped gas from die cavity during compaction. 
WSRC-TR-2001-00283

Revision 0

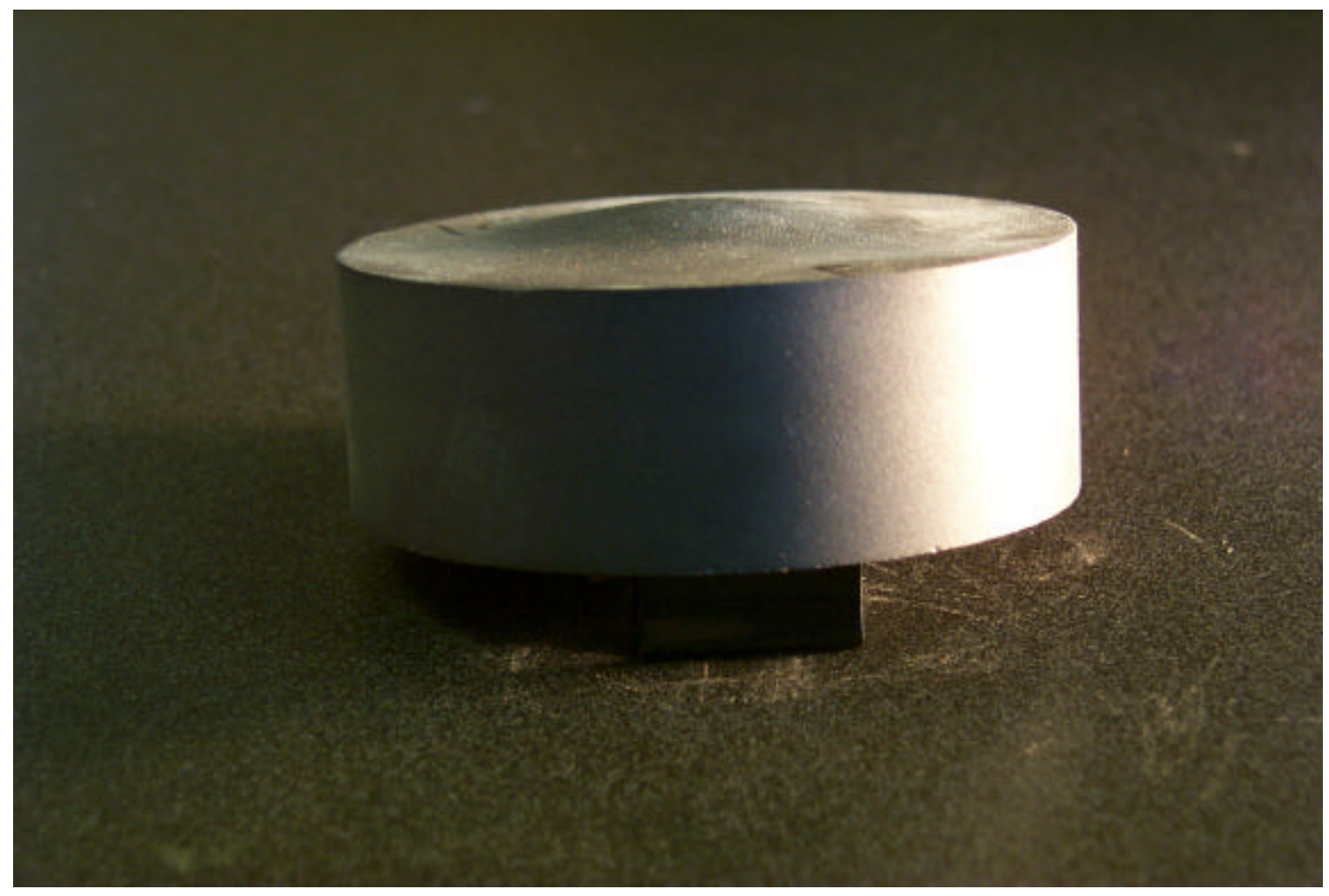

Figure 7: A bulge was observed in the top of sintered pucks in which the decomposition gases caused internal pressure. Excessive heating rates or the elimination of the $300^{\circ} \mathrm{C}$ caused sufficient internal pressures to deform the pucks as they were heated. 
WSRC-TR-2001-00283

Revision 0

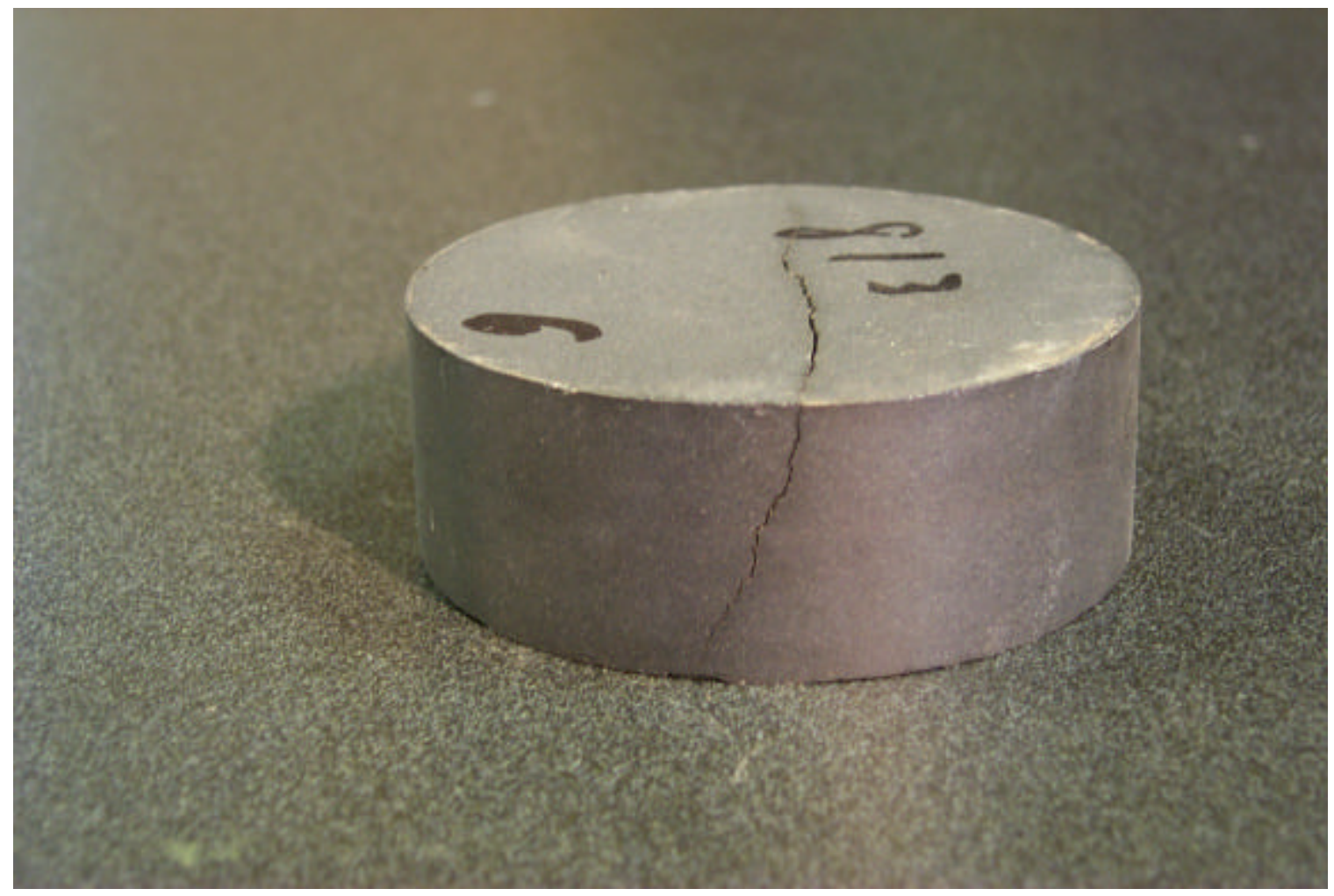

Figure 8: Radial cracks were caused by differential sintering stresses when the entire puck was not heated uniformly. Surface cooling by excessive purge rates was observed to cause radial cracking of pucks sintered in the lab-scale furnace and in the production furnace. 
WSRC-TR-2001-00283

Revision 0

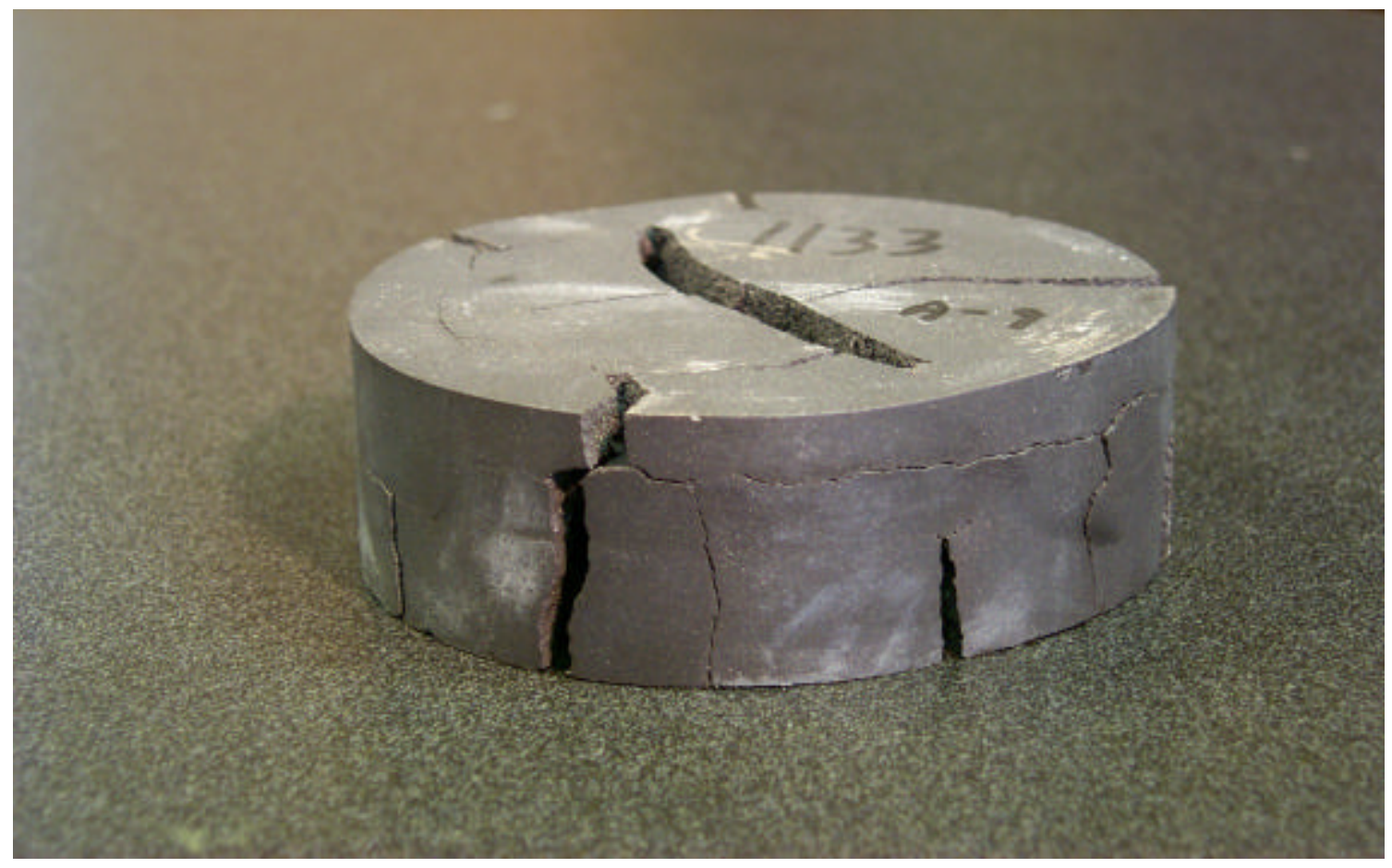

Figure 9: Impurity composition A-9 fabricated using standard processing conditions. Although the puck was still integral, the swelling caused by open cracks caused the puck diameter to exceed the maximum limit that would fit into a can. 
WSRC-TR-2001-00283

Revision 0

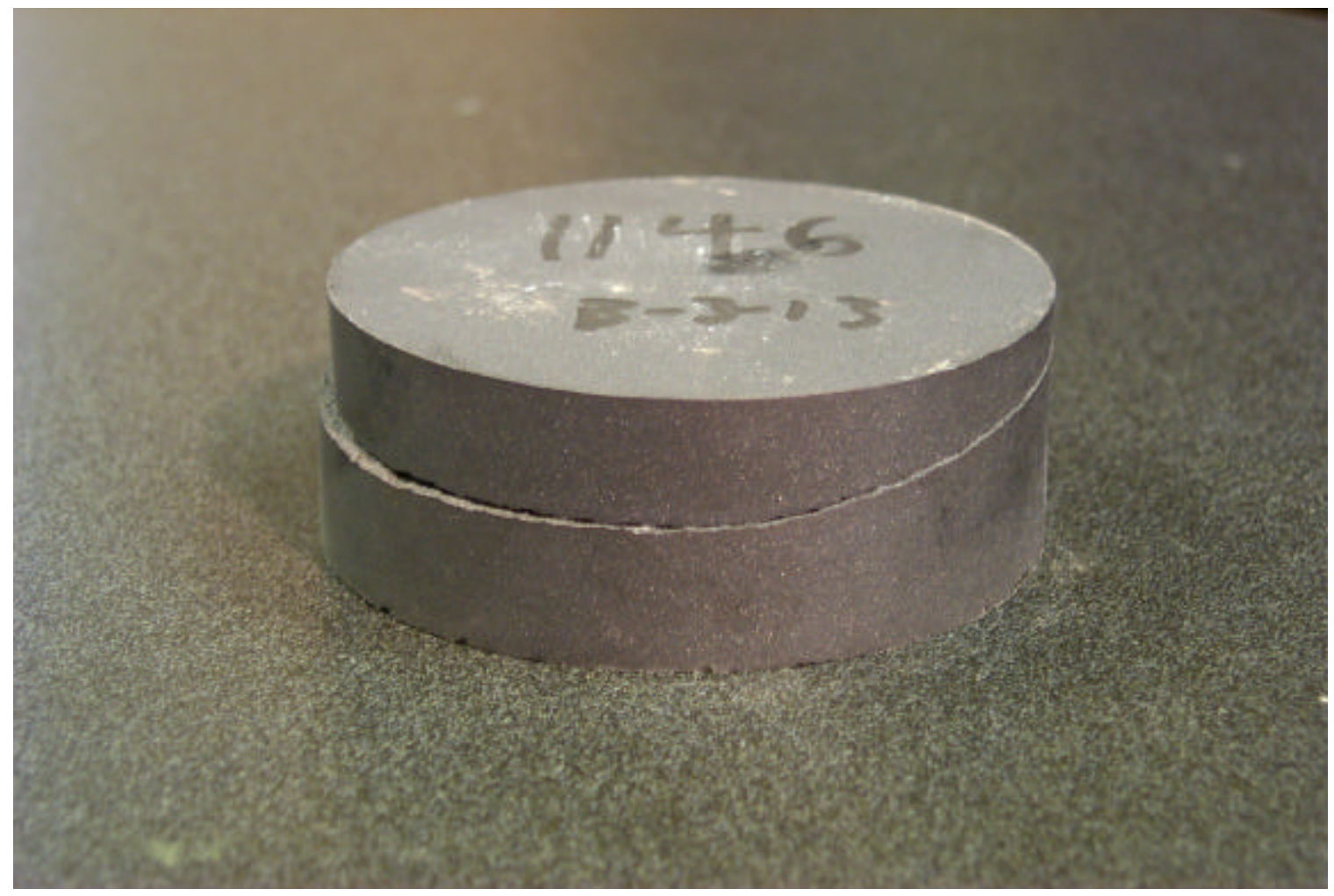

Figure 10: Impurity composition B3-13 fabricated using standard processing conditions. The puck was integral, however, a large lamination crack could cause handling problems since the puck could easily be fractured. 
WSRC-TR-2001-00283

Revision 0

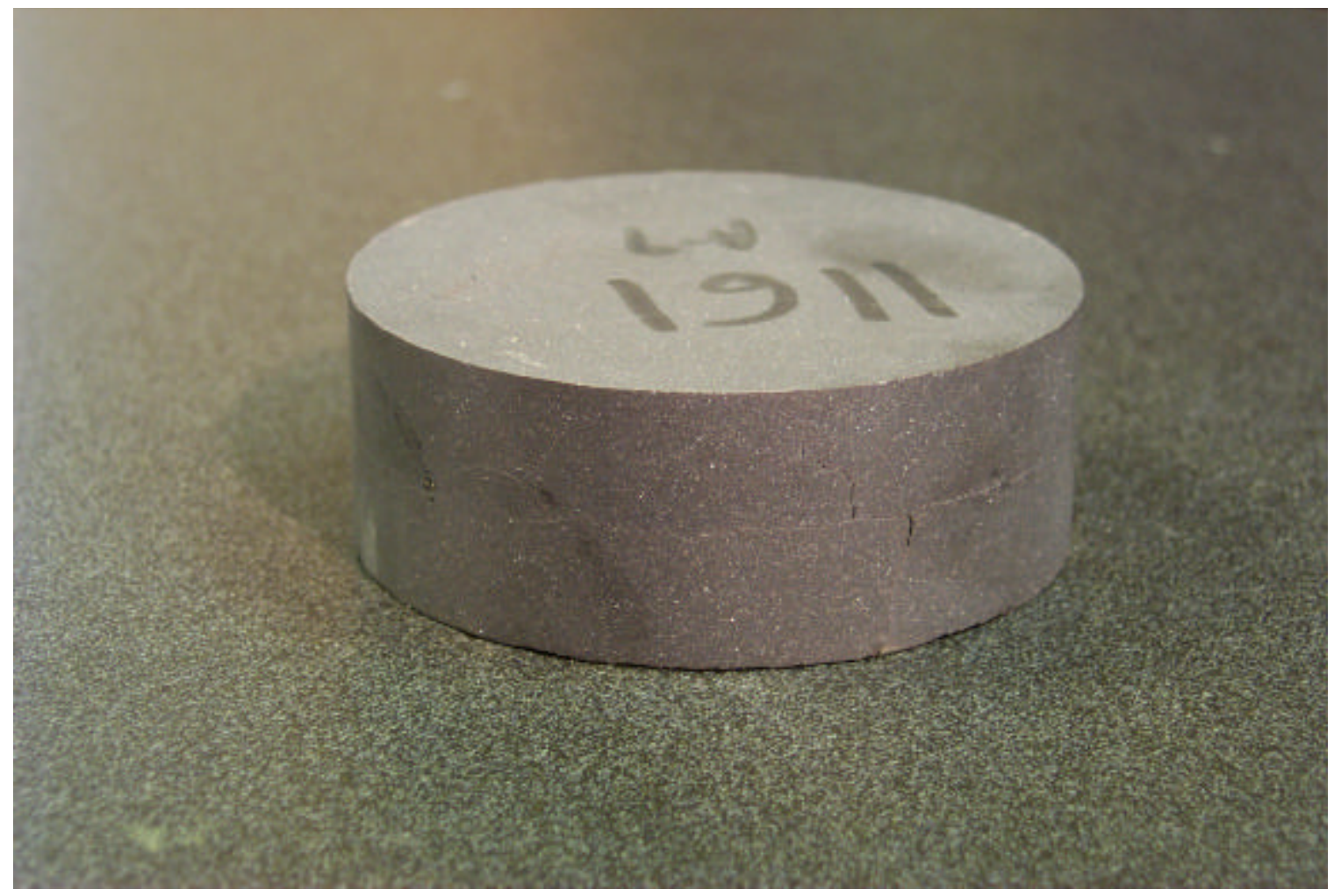

Figure 11: Impurity composition $\mathrm{A}-9$ heated at $3^{\circ} \mathrm{C} /$ minute with one hour holds at $300^{\circ} \mathrm{C}$ and $700^{\circ} \mathrm{C}$. Minor cracking was observed, however, the dimensions of the puck are within specifications. 
WSRC-TR-2001-00283

Revision 0

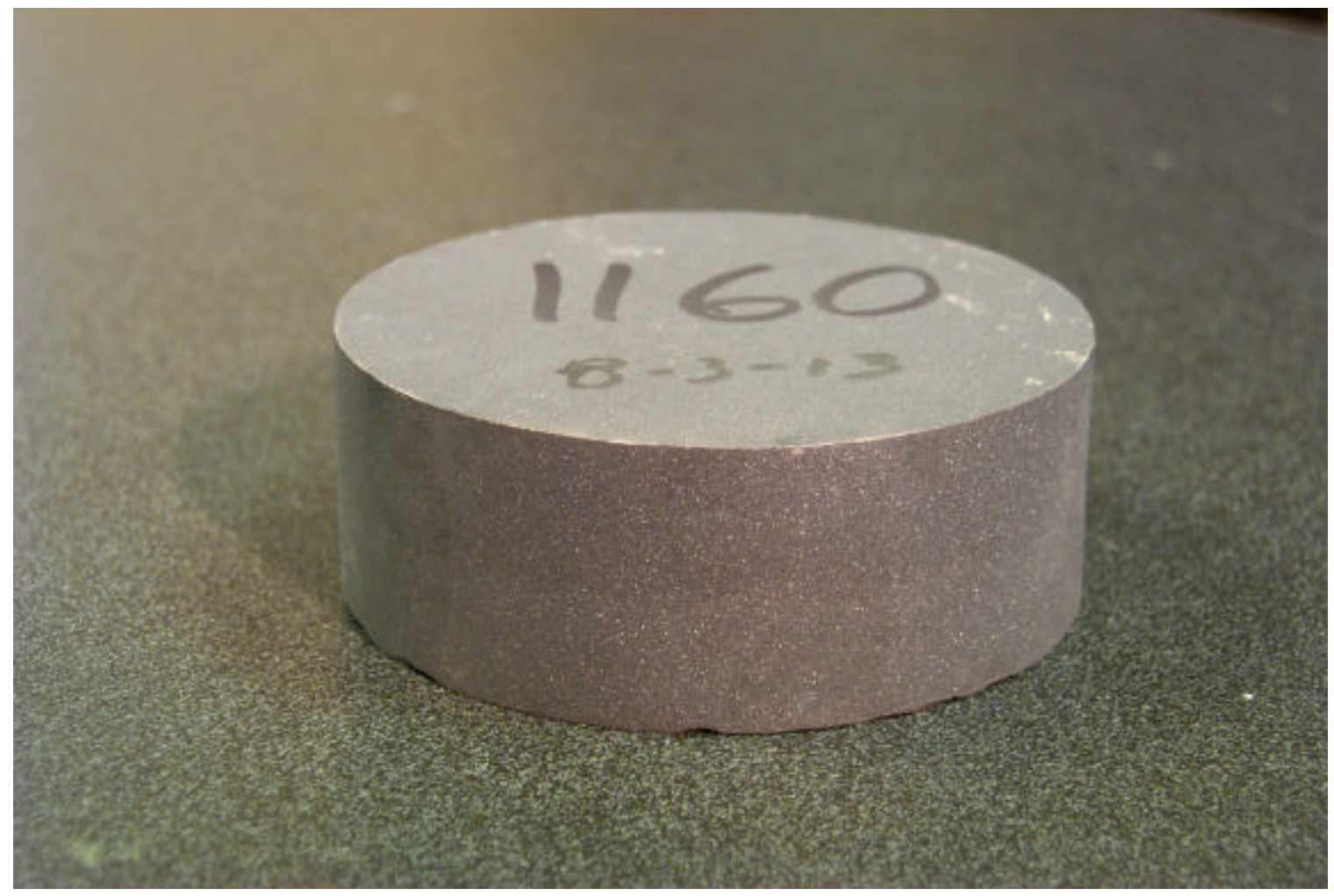

Figure 12: Impurity composition B3-13 heated at $3^{\circ} \mathrm{C} /$ minute with one hour holds at $300^{\circ} \mathrm{C}$ and $700^{\circ} \mathrm{C}$. Minor cracking was observed on the bottom of the puck, however, the dimensions of the puck are within specifications. The cracks on the bottom of the impurity pucks were attributed to low melting impurity phases or glasses that cause the pucks to stick to the setter plates, create stresses during sintering. 
WSRC-TR-2001-00283

Revision 0

Table 1: A-9 Impurity Composition

\begin{tabular}{|l|c|c|}
\hline & A-9 & A-9 \\
\hline Precursors & Pu-U & Ce-Ce \\
\hline + Actinides & (wt \%) & (wt \%) \\
\hline $\mathrm{CaO}$ & \multicolumn{1}{c|}{9.00} & 10.29 \\
\hline $\mathrm{TiO}_{2}$ & 35.84 & 40.96 \\
\hline $\mathrm{HfO}_{2}$ & 10.52 & 12.04 \\
\hline $\mathrm{Gd}_{2} \mathrm{O}_{3}$ & 7.19 & 8.22 \\
\hline $\mathrm{CeO}_{2}$ & -- & 23.37 \\
\hline $\mathrm{UO}_{2}$ & 22.10 & -- \\
\hline $\mathrm{PuO}_{2}$ & 10.22 & -- \\
\hline & & \\
\hline Impurities & & \\
\hline $\mathrm{Al}_{2} \mathrm{O}_{3}$ & 0.50 & 0.50 \\
\hline $\mathrm{MgO}_{\mathrm{CaCl}_{2}}$ & 0.44 & 0.44 \\
\hline $\mathrm{Ga}_{2} \mathrm{O}_{3}$ & 0.66 & 0.66 \\
\hline $\mathrm{Fe}_{2} \mathrm{O}_{3}$ & 0.57 & 0.57 \\
\hline $\mathrm{Cr}_{2} \mathrm{O}_{3}$ & 0.15 & 0.15 \\
\hline $\mathrm{NiO}$ & 0.08 & 0.08 \\
\hline $\mathrm{CaF}_{2}$ & 0.13 & 0.13 \\
\hline $\mathrm{K}_{2} \mathrm{O}$ & 0.44 & 0.44 \\
\hline $\mathrm{Na}_{2} \mathrm{O}$ & 0.32 & 0.32 \\
\hline $\mathrm{MoO}_{3}$ & 0.14 & 0.14 \\
\hline $\mathrm{SiO}_{2}$ & 0.28 & 0.28 \\
\hline $\mathrm{Ta}_{2} \mathrm{O}_{5}$ & 0.46 & 0.46 \\
\hline $\mathrm{B}_{2} \mathrm{O}_{3}$ & 0.19 & 0.19 \\
\hline $\mathrm{WO}_{3}$ & 0.17 & 0.17 \\
\hline $\mathrm{ZnO}$ & 0.49 & 0.49 \\
\hline $\mathrm{Total}$ & 0.07 & 0.07 \\
\hline & 100.0 & 100.0 \\
\hline
\end{tabular}


WSRC-TR-2001-00283

Revision 0

Table 2: B3-13 Impurity Composition

\begin{tabular}{|c|c|c|}
\hline & B3-13 & B3-13 \\
\hline & $($ wt \%) & (wt \%) \\
\hline $\begin{array}{l}\text { Base Feed } \\
\text { Materials }\end{array}$ & Pu-U & $\mathrm{Ce}-\mathrm{Ce}$ \\
\hline $\mathrm{CaO}$ & 8.300 & 10.29 \\
\hline $\mathrm{TiO}_{2}$ & 33.804 & 40.96 \\
\hline $\mathrm{HfO}_{2}$ & 10.270 & 12.04 \\
\hline $\mathrm{Gd}_{2} \mathrm{O}_{3}$ & 7.519 & 8.22 \\
\hline $\mathrm{UO}_{2}$ & 22.312 & -- \\
\hline $\mathrm{PuO}_{2}$ & 11.200 & -- \\
\hline $\mathrm{CeO}_{2}$ & 0.184 & 23.37 \\
\hline \multicolumn{3}{|l|}{ Impurities } \\
\hline $\mathrm{Al}_{2} \mathrm{O}_{3}$ & 0.723 & 0.723 \\
\hline $\mathrm{B}_{2} \mathrm{O}_{3}$ & 0.101 & 0.101 \\
\hline $\mathrm{BaO}$ & 0.143 & $--^{*}$ \\
\hline $\mathrm{CaCl}_{2}$ & 0.667 & 0.667 \\
\hline $\mathrm{Cr}_{2} \mathrm{O}_{3}$ & 0.050 & $--^{*}$ \\
\hline $\mathrm{CuO}$ & 0.117 & 0.117 \\
\hline $\mathrm{CaF}_{2}$ & 1.025 & 1.025 \\
\hline $\mathrm{Fe}_{2} \mathrm{O}_{3}$ & 0.187 & 0.187 \\
\hline $\mathrm{Ga}_{2} \mathrm{O}_{3}$ & 0.387 & 0.387 \\
\hline $\mathrm{K}_{2} \mathrm{O}$ & 0.225 & 0.225 \\
\hline $\mathrm{La}_{2} \mathrm{O}_{3}$ & 0.017 & 0.017 \\
\hline $\mathrm{MgO}$ & 0.433 & 0.433 \\
\hline $\mathrm{MnO}$ & 0.000 & 0.000 \\
\hline $\mathrm{MoO}_{3}$ & 0.161 & 0.161 \\
\hline $\mathrm{Na}_{2} \mathrm{O}$ & 0.232 & 0.232 \\
\hline $\mathrm{NiO}$ & 0.086 & 0.086 \\
\hline $\mathrm{Nd}_{2} \mathrm{O}_{3}$ & 0.291 & 0.291 \\
\hline $\mathrm{P}_{2} \mathrm{O}_{5}$ & 0.006 & 0.006 \\
\hline $\mathrm{PbO}$ & 0.516 & 0.516 \\
\hline $\mathrm{SiO}_{2}$ & 0.880 & 0.880 \\
\hline $\mathrm{SnO}_{2}$ & 0.006 & 0.006 \\
\hline $\mathrm{Ta}_{2} \mathrm{O}_{5}$ & 0.080 & 0.080 \\
\hline $\mathrm{WO}_{3}$ & 0.017 & 0.017 \\
\hline $\mathrm{ZnO}$ & 0.060 & 0.060 \\
\hline total & 100 & 100 \\
\hline
\end{tabular}

*RCRA metal omitted from composition. 